\title{
Effects of non-native Spartina patens on plant and sediment organic matter carbon incorporation into the local invertebrate community
}

\author{
Henry M. Page • Mariano Lastra • Iván F. Rodil • \\ María Jesús I. Briones · Josefina Garrido
}

Received: 11 May 2009/Accepted: 14 May 2010/Published online: 29 May 2010

(C) The Author(s) 2010. This article is published with open access at Springerlink.com

\begin{abstract}
The cycling of organic matter through food webs is a fundamental process that may be altered by the invasion of non-indigenous plants. We explored consequences of the invasion of non-indigenous Spartina patens to the composition of soil organic matter (SOM) and to detritivore and herbivore diets in the upper salt marsh within Corrubedo National Park, northwest Spain. We tested for the incorporation of $S$. patens carbon (C) into SOM and by detritivores and herbivores using stable isotope analysis, focusing primarily on detritivorous enchytraeid oligochaetes and herbivorous insects. Stable isotope results indicated that C derived from $S$. patens has been incorporated into SOM. Elevated densities of enchytraeids in stands of $S$. patens, and their incorporation of $\mathrm{C}$ derived from this plant, suggested that dense patches of $S$. patens may facilitate detritivore populations. In contrast, although insect herbivores used $S$. patens as habitat, there was little isotopic evidence for the widespread incorporation of S. patens-derived C by these consumers. The population and dietary response of enchytraeids to S. patens suggests that $S$. patens invasion could indirectly
\end{abstract}

H. M. Page ( $\square)$

Marine Science Institute, University of California, Santa Barbara, CA 93106, USA

e-mail: page@lifesci.ucsb.edu

M. Lastra · I. F. Rodil · M. J. I. Briones · J. Garrido Departamento de Ecología y Biología Animal, Universidad de Vigo, 36310 Vigo, Spain influence soil processes and pathways mediated by detritivore activity (e.g., soil respiration rates, nutrient retention and transformation, energy flow). The loss of food resources to insect herbivores alters local food webs. However, insect herbivores may move and feed on native plants elsewhere. As a result, insect populations may be less immediately impacted than soil detritivore populations by $S$. patens. Our study suggests that the influences of $S$. patens invasion extend beyond the more obvious changes in native plant abundance, to include differing responses in the cycling of organic matter between detritivore and insect herbivore food web pathways.

Keywords Invasive Spartina - Detritus - Salt marsh · Food web · Sap-feeding · Insect · Oligochaete

\section{Introduction}

Invasions of exotic plants have been identified as significant threats to native biodiversity and ecosystem functioning world-wide (e.g., Hobbs and Huenneke 1992; Cronk and Fuller 1995; Vitousek et al. 1996; Mack et al. 2000; Simberloff 2005), and coastal wetland ecosystems are dramatically impacted by these invasions (Chambers et al. 1999; Talley and Levin 2001; Ayres et al. 2004; Gratton and Denno 2006). Among the more successful invaders of coastal wetlands are grasses of the genus Spartina (e.g., Spartina alterniflora, S. anglica, S. densifolia) that 
have been introduced and successfully spread over large geographical areas, in some cases hybridizing with native Spartina species (Callaway and Josselyn 1992; Castillo et al. 2000; Nieva et al. 2001; Ayres et al. 2004; Zhang et al. 2004; Nehring and Hesse 2008; Renny-Byfield et al. 2010).

The impact of Spartina invasions on low intertidal and non-vegetated mudflat habitat has received considerable attention recently (e.g., Dethier and Hacker 2005; Neira et al. 2005; Cheng et al. 2006; Levin et al. 2006; Wu et al. 2009). However, there remains a paucity of information on the ecological effects of Spartina invasions on the upper salt marshtransition habitat although there is reason to believe that such effects may be appreciable. For example, non-indigenous Spartina have been inferred to outcompete native plants in the upper intertidal (summary in Daehler and Strong 1996; SanLeón et al. 1999), and shown to alter soil properties (Neira et al. 2006; Cheng et al. 2006), and benthic invertebrate community structure and trophic relationships in the lower intertidal (Neira et al. 2005; Levin et al. 2006; Chen et al. 2007).

Spartina patens (salt marsh hay, salt meadow cordgrass), native to the Atlantic and Gulf coasts of North America, is an invader of upper marsh habitat that has been introduced to the Pacific coasts of Canada (British Columbia) and the United States (Washington, Oregon, California), and to the Mediterranean (Callaway and Josselyn 1992; Frenkel and Boss 1988; Ayres et al. 2004). S. patens has also invaded the salt marshes of the northern Iberian Peninsula (e.g., Galicia, Spain) where it can be found in nearly monospecific stands in the upper high marsh (SanLeón et al. 1999).

The invasion history of Spartina patens on the Atlantic coast of Europe is ambiguous, but it has likely been present for many decades, perhaps originally introduced as packing material in shipping boxes and crates at ports in the Mediterranean in the nineteenth century and then spreading up the Iberian Peninsula (SanLeón et al. 1999 and references therein). In its native range, this plant is typically found above mean high water (MHW) (Blum 1968; Redfield 1972), a pattern related to a lower tolerance of anoxic soils in the lower intertidal (Bertness 1991).

Among the ecological functions of coastal wetlands that could be affected by the invasion of Spartina patens are the provision of habitat and trophic support. Plants provide habitat via vertical and horizontal above and belowground structure and trophic support through the production of organic matter that is used by detritivores (e.g., leaf litter, roots, associated microbes) and by herbivores (plant sap, living leaves). Non-indigenous plants can differ from native species in rates of litter production, chemical composition, and palatability, attributes that may alter trophic structure and food web interactions through their effects on detrital (decomposer) and grazer (herbivore) pathways (Moore et al. 2004).

The upper marsh receives only occasional inundation, thus vascular plants rather than phytoplankton or benthic micro- and macroalgae most likely comprise the main source of primary production used by detritivores and herbivores in this habitat. The processing of organic matter by decomposers is considered the principle pathway of organic matter re-cycling (reviewed in Moore et al. 2004). Since Spartina patens occurs in thick monotypic stands (SanLeón et al. 1999; this study) that may accumulate litter at a faster rate than adjacent marsh vegetation (Frenkel and Boss 1988), we predicted that organic matter from this plant has altered the composition of SOM and the source of production used by soil detritivores in invaded habitat.

Some fraction of living plant production is also consumed by herbivores. A guild of herbivorous insects, primarily sap-feeding members of the Order Hemiptera is associated with living Spartina patens in its native habitat (Davis and Gray 1966; Raupp and Denno 1979; Denno 1980). These herbivores can attain high densities, tend to be plant host-specific, and support a food web that includes predaceous spiders and mirid bugs (Raupp and Denno 1979). However, less herbivory may occur on $S$. patens in invaded habitat if insect herbivores that would normally feed on this plant within its native range are absent. Little information is available on the use of non-indigenous Spartina by native insect herbivores (reviewed by Maron and Vilà 2001; but see Wu et al. 2009).

In this study, we explored the consequences of the Spartina patens invasion to the composition of soil organic matter (SOM) and to detritivore and herbivore diet at salt marsh sites in Corrubedo National Park, Galicia, northwest Spain. Specifically, we investigated the hypothesis that detritivores and insect herbivores vary in their use of S. patens, with organic matter from this source incorporated into marsh soil 
and infaunal detritivores, but not herbivorous insects. We tested for the use of $S$. patens derived $\mathrm{C}$ by detritivores and herbivores using stable isotope analysis, focusing primarily on representative "indicator" taxa-detritivorous enchytraeid oligochaetes (Annelida) and herbivorous insects of the Orders Hemiptera (Homoptera) and Orthoptera. Enchytraeids are thought to influence biogeochemical cycling in sediments through their tunneling and feeding activities (van Vliet et al. 2004). Herbivorous insects can feed extensively on and adversely influence $S$. patens in its native habitat (Denno 1980).

Stable isotope analysis has been widely used to evaluate the contribution of $\mathrm{C}_{3}$ versus $\mathrm{C}_{4}$ plantderived carbon to SOM (e.g., Boutton 1996; Cheng et al. 2006), and to the diets of soil detritivores (Martin et al. 1992; Briones and Schmidt 2004) and herbivorous arthropods (Fry et al. 1978; Petelle et al. 1979; Gratton and Denno 2006; Wu et al. 2009). Because isotopic differences between $\mathrm{C}_{3}$ and $\mathrm{C}_{4}$ plants are large (typically at least $10 \%$, reviewed in Fry 2006), we predicted that SOM in the Spartina zone would be ${ }^{13} \mathrm{C}$-enriched compared to SOM associated with native $\mathrm{C}_{3}$ plants. The use of Spartinaderived $\mathrm{C}$ by detritivores and herbivores should also be evident by ${ }^{13} \mathrm{C}$-enriched signatures of these organisms sampled from patches of $S$. patens compared to those associated with the native $C_{3}$ plants.

\section{Materials and methods}

Study site

We conducted this study within the $\sim 1 \mathrm{~km}^{2}$ area tidal wetland of the Corrubedo National Park located in Galicia, NW Spain $\left(42^{\circ} 34^{\prime} 20^{\prime \prime} \mathrm{N}, 9^{\circ} 2^{\prime} 6^{\prime \prime} \mathrm{W}\right.$ : Fig. 1). Spartina patens is widely distributed in the upper high marsh within the Park (SanLeón et al. 1999). To test for the incorporation of $S$. patens detritus into the soil organic matter pool and use by detritivores and herbivores, we sampled three sites that differed in the cover of $S$. patens and two native plants (Limonium dodartii and Juncus maritimus). One site (A) possessed three distinct vegetation zones dominated by L. dodartii, S. patens, and J. maritimus, from higher to lower elevation, respectively. The second site (B), located approximately $150 \mathrm{~m}$ to the north of site A possessed well-delineated zones of $S$. patens and
$J$. maritimus, but lacked the L. dodartii zone. The last site (C), $80 \mathrm{~m}$ to the south of site A, possessed L. dodartii and J. maritimus, but lacked the S. patens zone.

Differences in the distribution and cover of these plant species was related, at least in part, to the elevation and topography of the marsh plain (unpublished data, Sánchez et al. 1996). The lower limit of Juncus maritimus corresponded approximately with mean high water $(\sim+3 \mathrm{~m}$ relative to the most extreme low water spring tide, ELWS), whereas the lower limit of Spartina patens corresponded approximately with mean high water spring tides $(\sim+3.5 \mathrm{~m}$ ELWS) (personal observation). Although Limonium dodartii, S. patens, and J. maritimus comprised collectively the highest cover of plants on the marsh plain, other species were present, including sparse cover of the native $\mathrm{C}_{3}$ grass Festuca rubra subsp. littoralis at the upper elevations of site $\mathrm{C}$, and the native $\mathrm{C}_{3}$ plants Sarcocornia perennis, L. vulgare, Halimione portulacoides, and Inula crithmoides at lower elevations at all sites.

Vegetation characteristics and soil properties

We estimated the species composition and cover of vegetation at each site along transect lines that extended perpendicular to the water line in May 2008. Species and cover were recorded within a $50 \times 50 \mathrm{~cm}$ quadrat spaced at $2 \mathrm{~m}$ intervals along the transect. At sites $\mathrm{A}$ and $\mathrm{B}$, data were recorded from three transects located 3-5 m apart; one transect only was sampled at site $\mathrm{C}$. The quadrat was divided into 100 squares and percent cover for a given species (or bare space) was estimated visually by counting the number of squares occupied by $50 \%$ or greater of that species. Relative change in elevation of the marsh plain was also measured at $2 \mathrm{~m}$ intervals at each site using a transit level.

The percentage of $\mathrm{C}$ and $\mathrm{N}$ in the SOM at all sites was determined at the same time that soil samples were analyzed for stable $\mathrm{C}$ and $\mathrm{N}$ isotopes (see below). We also sampled soil at sites A and B (see below) to determine grain size characteristics within the discrete vegetation zones. Soil samples were wet sieved on an analytical sieve shaker (Retsch AS-200) and categorized in terms of percentage composition of silt-clay $(<63 \mu)$ and sand $(\geq 63 \mu)$ (Wentworth 1922). 


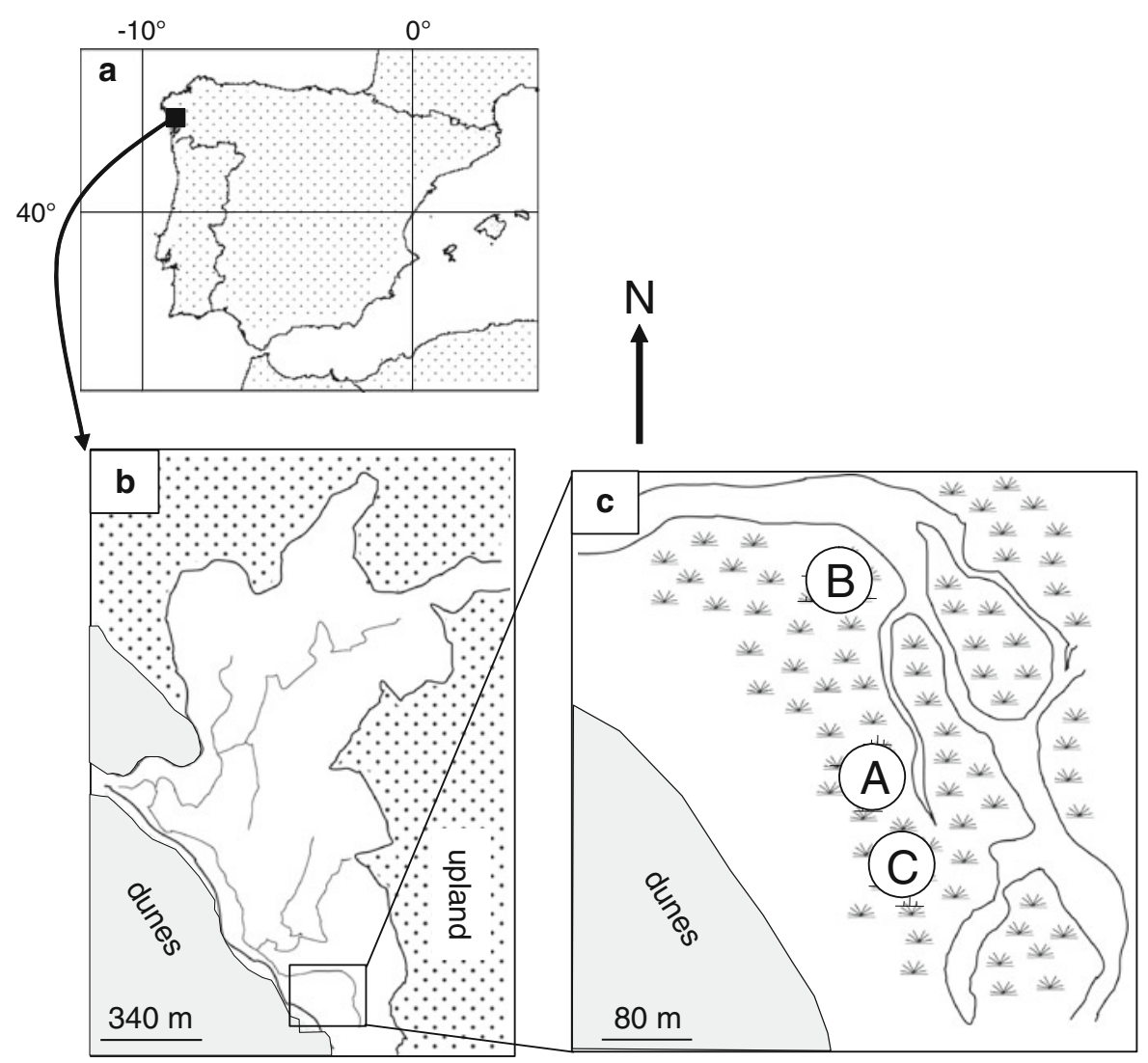

Fig. 1 Location of a Corrubedo National Park on the Iberian Peninsula, b the study area within the Corrubedo wetlands, and $\mathbf{c}$ the study sites

Sampling and processing of plants, soil and enchytraeids

To determine the isotope values of the dominant marsh plants, we collected samples on 21-28 May 2008 of Limonium dodartii, L. vulgare, and Spartina patens. We also collected samples of less abundant species, including Sarcocornia perennis, Halimione portulacoides, and Festuca rubra subsp. littoralis, and, from site B, samples of filamentous green algae that were sparsely distributed at the lower elevations of this site. Live leaf tissue was collected from several plants and composited to form one sample. At least three samples were collected of the dominant plant species (one from each site). Plant and algae samples were rinsed in de-ionized water, dried at $65^{\circ} \mathrm{C}$ for 24 $48 \mathrm{~h}$, and ground using a ball mill (Pulverisette 2, Fritsch) in preparation for isotope analysis.

To determine the isotopic composition of SOM, and the density and isotopic composition of enchytraeids, soil cores were taken to a depth of $5 \mathrm{~cm}$ along one transect line within each site in May 2008. Samples were collected in 4 or 5 paired $7 \mathrm{~cm}$ diameter cores spaced equally within each of the Limonium, Spartina, and Juncus vegetation zones (if present, see above). Enchytraeid oligochaetes were separated from the soil using a modified wet funnel extraction (O'Connor 1955), counted, and freeze-dried in preparation for isotope analysis. The biomass of worms in individual core samples collected from the Limonium zone was not sufficient for isotope analysis. Consequently, all samples taken within this zone (sites A and C) were pooled for analysis ( $n=1$ from each site).

A subsample of soil from the core taken from 2 to $5 \mathrm{~cm}$ depth was dried, sieved through $1 \mathrm{~mm}$ mesh to remove root and other debris, and inspected under a dissecting microscope, where any obvious remaining root material was removed. The soil sample was then treated with $10 \% \mathrm{HCl}$ to remove carbonates, re-dried, and ground using a mortar and pestle. 
Sampling and processing of arthropods

To determine the relative abundance of herbivorous insect taxa and to sample insect herbivores and spiders for isotope analysis within each vegetation zone, we conducted net sweeps using a $50 \mathrm{~cm}$ diameter insect net while walking through the vegetation at each site (e.g., Denno 1977, 1980). Twenty to and fro net sweep samples were taken at mid-day along three longitudinal transects within each vegetation zone at each site such that the upper portion of the vegetation was hit by the net. These data provide a comparative "snapshot" of insect use of the three vegetation zones, but a more comprehensive sampling program, including vacuum sampling to better sample insects within the lower strata of vegetation, and temporal replication would be necessary to compare actual insect densities among zones.

Whenever possible, isotope analyses were performed on triplicate samples of insects or spiders collected in the net sweeps. Three individual planthoppers or leafhoppers were pooled to produce one sample for analysis. Individual grasshoppers and spiders were processed for analysis. Insect and spider samples were dried as above and gently crushed in a mortar and pestle prior to isotope analysis.

\section{Isotope analyses}

Isotope analyses of the soil, plant, and arthropod samples were conducted at the Servizos de Apoio a Investigacion (SAI), University of A Coruña. Samples were analyzed using a ThermoFinnigan Flash EA 1112 elemental analyzer (Thermo Electron Corporation, Bremen, Germany) coupled with a Finnigan Delta Plus isotope ratio mass spectrometer (IRMS). Enchytraeid worms were analyzed at the Macaulay Land Use Research Institute (Craigiebuckler, Aberdeen, Scotland) using a Flash EA 1112 elemental analyzer coupled with a Delta Plus IRMS. Isotope values for carbon and nitrogen were calculated as: $\delta^{n} X=\left(R_{\text {sample }} / R_{\text {standard }}-1\right) \times 1,000$, where $X=$ $\mathrm{C}$ (carbon) or $\mathrm{N}$ (nitrogen) and $R={ }^{13} \mathrm{C} /{ }^{12} \mathrm{C}$ for $\mathrm{C}$ and ${ }^{15} \mathrm{~N} /{ }^{14} \mathrm{~N}$ for $\mathrm{N}$. Values are reported per mil (\%o) relative to the $\mathrm{PDB}$ standard for $\mathrm{C}$ and atmospheric $\mathrm{N}_{2}$ for $\mathrm{N}$; analytical precision for $\mathrm{C}$ and $\mathrm{N}$ isotope values from both laboratories was $\pm 0.2 \%$.
Data analysis

Analysis of covariance (ANCOVA) was used to test for significant differences in $\delta^{13} \mathrm{C}$ and $\delta^{15} \mathrm{~N}$ values of SOM and enchytraeid oligochaetes, and enchytraeid densities among sites as a function of cover of Spartina patens. Site was treated as a categorical variable and cover of $S$. patens as a covariate. We evaluated the assumption of homogeneity of sample variances using Levine's (2003) test and $\log (x+1)$ transformed data (enchrytraeid densities) when this assumption was violated. Correlation and regression analysis was used to explore relationships between the isotope values of SOM and enchrytraeids.

We made a coarse estimate of the contribution of $\mathrm{C}_{4}-\mathrm{C}$ (Spartina patens) to SOM in the Spartina vegetation zone using a two-source mixing model (method reviewed in Fry 2006; Cheng et al. 2006): $f=\left(\begin{array}{lll}\delta_{\mathrm{SOM}} \text { Mix } & -\delta_{\mathrm{C} 3} \text { sOM }\end{array}\right) /\left(\begin{array}{l}\delta_{\text {Spartina }}-\delta_{\mathrm{C} 3} \text { sOM }\end{array}\right)$, where $f=$ the proportional contribution $\mathrm{C}_{4}-\mathrm{C}$ to $\mathrm{SOM}$ in the Spartina zone, $\delta_{\mathrm{SOM} \text { Mix }}=\delta^{13} \mathrm{C}$ value of SOM in Spartina zone, $\delta_{\mathrm{C} 3}$ som $=\delta^{13} \mathrm{C}$ value of $\mathrm{SOM}$ in $\mathrm{C}_{3}$ plant zones, and $\delta_{\text {Spartina }}=\delta^{13} \mathrm{C}$ value of Spartina patens. Calculations of $f$ and $95 \%$ confidence intervals around this value were made using Isoerror 1.04 (Phillips and Gregg 2001).

We made a similar assumption to that of Cheng et al. (2006) that the mean $\delta^{13} \mathrm{C}$ value of SOM from the $\mathrm{C}_{3}$ plant (in our case Limonium, Juncus) zones represented that of the SOM in the Spartina zone prior to invasion. This assumption was necessary because there is no "before" invasion data; however, it does not seem unreasonable since Limonium and Juncus overlap the elevational distribution of S. patens and were probably plant dominants in the Spartina zone prior to invasion. Among potential sources of error in estimates of the contribution of Spartina $\mathrm{C}$ to SOM are changes that may occur in the $\delta^{13} \mathrm{C}$ value of plants during decomposition. These changes for the conspecific Spartina alterniflora have been reported to range from 0 during aerial decomposition (Ember et al. 1987; Currin et al. 1995) to $\sim-1-2 \%$ for litter buried for over 1 year (Ember et al. 1987; Benner et al. 1987), with larger changes predicted to occur over time by modeling (Benner et al. 1987). S. patens occurs at higher tidal elevations than $S$. alterniflora and it is unknown to what extent these changes apply at our site. However, to explore the sensitivity of model output to variation in the value of $S$. patens, we 
calculated the potential contribution of Spartina C to SOM under three scenarios that encompass reported or projected changes in this value during decomposition of $S$. alterniflora.

\section{Results}

Vegetation characteristics and soil properties

Spartina patens occurred in highest cover (to 95\%) in a band of $\sim 10 \mathrm{~m}$ in width above the zone dominated by Juncus maritimus at sites A and B, whereas it was absent from a similar elevation range at site $\mathrm{C}$ (between 0.0 and $-0.2 \mathrm{~m}$ relative elevation, Fig. 2). Limonium dodartii occurred at the highest elevation in discontinuous patches that varied in width from $\sim 7$ to $10 \mathrm{~m}$ that were intermingled with bare space (to $48 \%$ cover at site A). This plant was absent at site B, where the upper elevation was covered with wrack consisting of dead vegetation (primarily S. patens). J. martimus occurred in highest cover (to 95\%) at lower elevations in a band that varied in width from $\sim 10 \mathrm{~m}$ at site $\mathrm{A}$ to $\sim 30 \mathrm{~m}$ at sites $\mathrm{B}$ and $\mathrm{C}$. Other plants, notably Halimione portulacoides and Sarcocornia perennis, were present in a narrow band of a few meters in width below J. maritimus and adjacent to tidal creeks. The native Spartina maritima, which occurs at lower elevations within the Corrubedo wetlands, was not present in our study area.

Soil properties varied among vegetation zones with soil from the lower elevation Juncus zone containing a higher proportion of fine sediments (siltclay), and having a higher organic $\mathrm{C}$ content than soil from the Limonium and Spartina zones (Table 1).

Distribution and densities of enchytraeid oligochaetes

Across all vegetation zones and sites, the density of enchytraeids was highly variable in individual samples, ranging from 259 to $55,873 \mathrm{~m}^{-2}$. There was a significant site $\times$ Spartina interaction effect on mean enchytraeid densities $\left(P=0.048, \quad F_{1,30}=4.244\right.$, ANCOVA); therefore, densities among vegetation zones were compared within each site. The mean density of enchytraeids was significantly higher in the Spartina zone than other vegetation zones at site A $\left(P=0.004, F_{2,12}=8.838\right)$. Mean enchytraeid densities were not higher in the Spartina zone at site B $(P=0.325, t=1.049, d f=8)$ where densities were highly variable among samples within this zone (range, 1,040-55,873 $\mathrm{m}^{-2}$ ) (Fig. 3). There was no difference in mean enchytraeid densities between the two vegetation zones (Limonium, Juncus) sampled at site C $(P=0.279, t=1.160, d f=8)$. Overall, there was a trend of higher and more variable densities of enchytraeids in the Spartina than in the Juncus or Limonium zones (Fig. 3).

Insect herbivores

Flies (Diptera) and planthoppers and leafhoppers (Hemiptera) comprised $>90 \%$ of insects captured in net sweeps within the Spartina ( $n=74$ insect specimens) and Juncus $(n=155)$ zones and $75 \%$ of insects captured within the Limonium zone $(n=42)$ (Fig. 4). The planthopper Pentastiridius leporinus (Hemiptera, Cixidae) was the most conspicuous herbivore comprising 55 and $25 \%$ of captured insects within the Spartina and Juncus zones, respectively. This is the first record of this species in Galicia, being reported previously from Aranjuez in central Spain and from Mallorca in the Balearic Archipelago, Mediterranean Sea (D. Aguin-Pombo, personal communication). A small percentage (1.4\%) of insects captured in the Spartina and Juncus zones were grasshoppers (Orthoptera, Acrididae) and katydids (Orthoptera, Tettigoniidae); these taxa comprised a higher percentage $(21 \%)$ of insects captured in the Limonium zone.

Isotopic composition of plants, soil organic matter and oligochaetes

As expected, mean $\delta^{13} \mathrm{C}$ values of Juncus maritimus and Limonium dodartii ( -26 to $-25 \%$ ) were within the range expected for $\mathrm{C}_{3}$ plants and distinct from the value for the $\mathrm{C}_{4}$ grass, Spartina patens $(-15.3 \%$ : Table 2). The $\delta^{13} \mathrm{C}$ value for filamentous green algae, which was present in low cover at site $\mathrm{B}$, was intermediate between the values for $\mathrm{C}_{3}$ and $\mathrm{C}_{4}$ plants. $\delta^{15} \mathrm{~N}$ values were similar among Juncus, Limonium, and Spartina and filamentous green algae $(-0.4-$ 0.5\%: Table 2).

$\delta^{13} \mathrm{C}$ values of SOM varied significantly with the cover of Spartina patens $\left(P<0.003, F_{1,18}=11.565\right)$ and site $\left(P=0.022, \quad F_{2,18}=4.776\right.$, ANCOVA $)$. 
Fig. 2 Percent cover of the most abundant plant species, bare space, and filamentous green macroalgae as a function of distance along transect lines perpendicular to the water line at our study sites in Corrubedo wetlands. $n=3$ transects $(\mathbf{a}, \mathbf{b})$, $n=1$ (c). Mean values $(\mathbf{a}, \mathbf{b}) \pm 1 \mathrm{SD}$
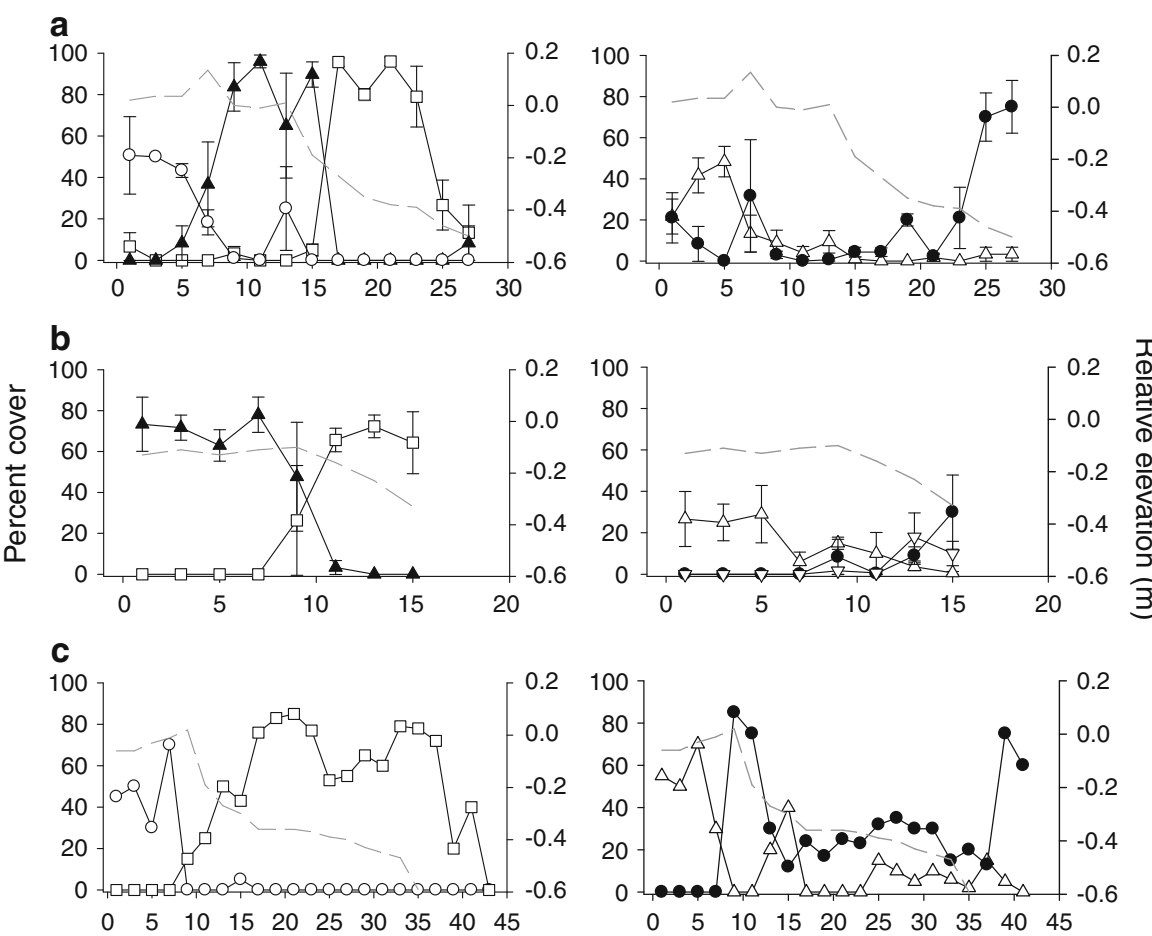

Distance (m)

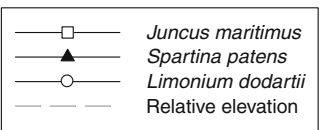

Table 1 Selected properties of soil sampled from the Limonium, Spartina, and Juncus vegetation zones

\begin{tabular}{llccrr}
\hline Site & Vegetation zone & \% silt-clay $(<63 \mu)$ & $\%$ sand $(\geq 63$ to $<4 \mu)$ & SOM $\% \mathrm{C}$ & SOM $\% \mathrm{~N}$ \\
\hline A & Limonium & $4.1 \pm 0.5$ & $93.1 \pm 0.4$ & $1.0 \pm 0.7$ & $0.1 \pm 0.0$ \\
& Spartina & $1.2 \pm 0.5$ & $92.2 \pm 2.8$ & $6.2 \pm 3.5$ & $0.7 \pm 0.3$ \\
& Juncus & $25.5 \pm 1.3$ & $53.7 \pm 3.4$ & $16.0 \pm 5.7$ & $1.3 \pm 0.3$ \\
B & Spartina & $1.9 \pm 0.8$ & $90.1 \pm 4.8$ & $2.2 \pm 1.0$ & $0.3 \pm 0.1$ \\
& Juncus & $27.8 \pm 19.4$ & $59.5 \pm 9.0$ & $4.2 \pm 3.5$ & $0.3 \pm 0.3$ \\
C & Limonium & - & - & $1.7 \pm 1.2$ & $0.1 \pm 0.0$ \\
& Juncus & - & - & $5.0 \pm 4.0$ & $0.5 \pm 0.4$
\end{tabular}

\% C measurements made following treatment of soil samples with HCl. Limonium and Spartina zones absent from sites B and C, respectively. $x \pm 1 \mathrm{SD}, n=4$. - , no data

Overall, SOM samples from the Spartina zone were ${ }^{13} \mathrm{C}$-enriched by $3.1 \%$ compared to SOM samples from the Limonium and Juncus zones (Table 3). There was a significant Spartina $\times$ site interaction on SOM $\delta^{15} \mathrm{~N}$ values $\left(P=0.039, F_{2,23}=3.739\right)$. However, the mean $\delta^{15} \mathrm{~N}$ value of SOM from the Spartina zone differed by only $0.5 \%$ from the mean value of SOM from the Limonium and Juncus zones (Table 3).
A similar pattern of ${ }^{13} \mathrm{C}$-enrichment in the Spartina zone was evident in the $\delta^{13} \mathrm{C}$ values of enchytraeid oligochaetes (Table 3). There was a significant effect of Spartina cover on enchytraeid $\delta^{13} \mathrm{C}$ values (Spartina, $P<0.001, F_{1,21}=18.359$; site, $P=0.961, F_{2,21}=0.040$, ANCOVA). Across sites, $\delta^{13} \mathrm{C}$ values of oligochaetes were highly correlated with the cover of $S$. patens $(P<0.001$, 


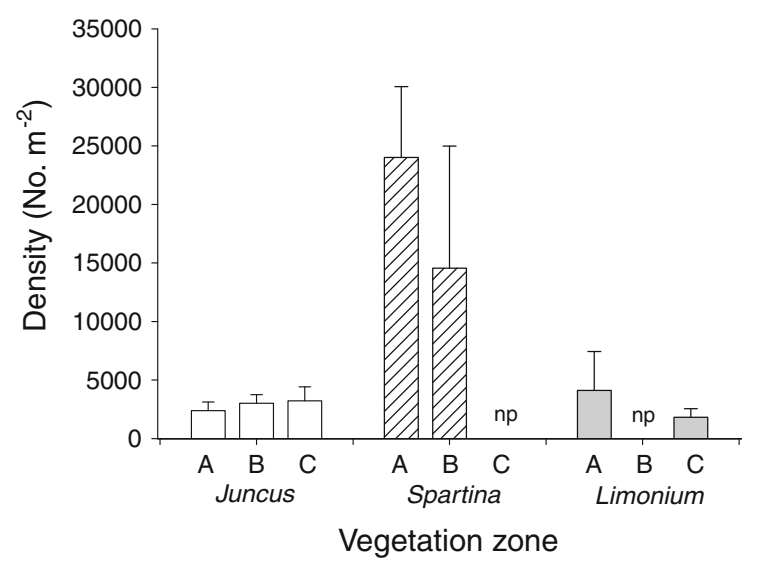

Fig. 3 Density of enchytraeid oligochaetes $\left(\mathrm{m}^{-2}\right)$ within zones of dominant vegetation (Juncus maritimus, Spartina patens, Limonium dodartii). np vegetation zone not present. Mean values $\pm 1 \mathrm{SD}, n=5$

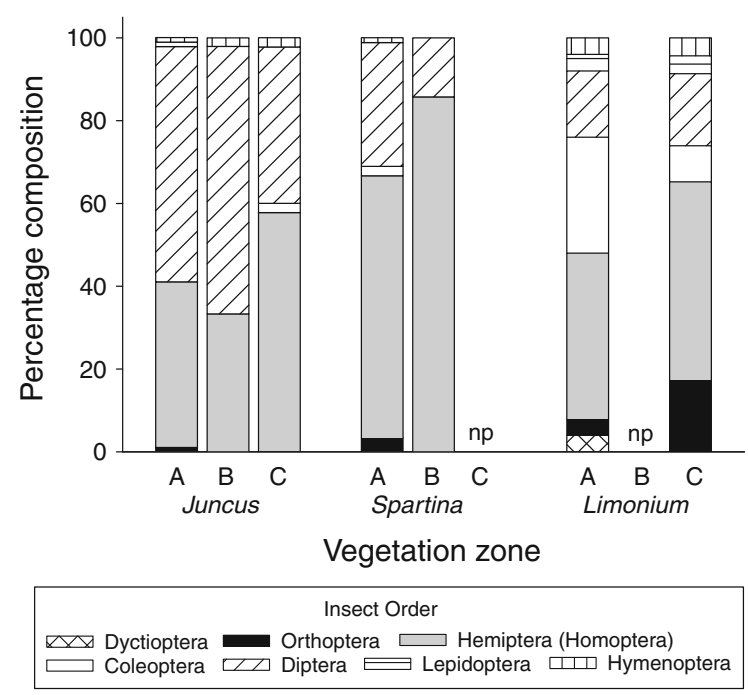

Fig. 4 Taxonomic composition of insects captured in net sweeps within vegetation zones dominated by Juncus maritimus, Spartina patens, and Limonium dodartii. Sample sizes provided in text. $n p$ vegetation zone not present

$r=0.720, n=25)$. Overall, enchytraeid $\delta^{13} \mathrm{C}$ values were $4 \%$ higher in the presence of $S$. patens $\left(-20.0 \pm 1.6 \%\right.$ ) than $\mathrm{C}_{3}$ plants $(-24.0 \pm 0.2 \%$ ) (Table 3). There was a significant Spartina $\times$ site interaction on enchytraeid $\delta^{15} \mathrm{~N}$ values $(P=0.039$, $\left.F_{2,20}=3.825\right)$; however, mean $\delta^{15} \mathrm{~N}$ values differed by $<1 \%$ between the Spartina and the Limonium and Juncus zones (Table 3).

There was a significant correlation between the $\delta{ }^{13} \mathrm{C}$ values of enchytraeids and SOM $(P<0.001$,
Table $2 \delta^{13} \mathrm{C}$ and $\delta^{15} \mathrm{~N}$ values (\%o) of salt marsh plant species in Corrubedo wetlands

\begin{tabular}{llll}
\hline Dominant plant species & $\delta^{13} \mathrm{C}(\%)$ & $\delta^{15} \mathrm{~N}(\%)$ & $n$ \\
\hline Limonium dodartii & $-25.7 \pm 0.4$ & $-0.4 \pm 0.7$ & 3 \\
Spartina patens & $-15.3 \pm 1.2$ & $-0.4 \pm 0.8$ & 3 \\
Juncus maritimus & $-26.2 \pm 0.6$ & $0.5 \pm 0.9$ & 6 \\
Other plant species & & & \\
$\quad$ Halimione portulcoides & -25.8 & 3.6 & 2 \\
$\quad$ Limonium vulgare & $-26.2 \pm 0.4$ & $0.8 \pm 0.4$ & 3 \\
$\quad$ Inula crithmoides & -28.6 & -0.3 & 2 \\
$\quad$ Sarcocornia perennis & $-29.5 \pm 3.4$ & $1.1 \pm 1.0$ & 3 \\
$\quad$ Festuca rubra subsp. & -28.0 & -2.1 & 1 \\
$\quad$ littoralis & & & \\
Alga & & & \\
$\quad$ Green macroalgae & $-22.8 \pm 0.9$ & $-0.5 \pm 0.6$ & 5 \\
$\quad$ filamentous) & & & \\
\hline
\end{tabular}

$x \pm 1 \mathrm{SD}, n=$ sample size

$r=0.653, n=22$ : Fig. 5a). A weak negative, but significant correlation occurred between $\delta^{15} \mathrm{~N}$ values of enchytraeids and SOM $(P=0.044, r=-0.444$, $n=22$ : Fig. 5b).

Results from mixing model calculations suggested that an average of from 35 to $63 \%$ of SOM at depths of $2-5 \mathrm{~cm}$ could be composed of $\mathrm{C}$ derived from Spartina patens, depending on the scenario of assumed change in $\delta^{13} \mathrm{C}$ values during plant decomposition (Table 4). Decreasing the $\delta^{13} \mathrm{C}$ value of $S$. patens increased the estimated contribution of this source. The significant correlation between $\delta^{13} \mathrm{C}$ values of enchytraeid oligochaetes and of SOM across $\mathrm{C}_{3}$ and $\mathrm{C}_{4}$ plant zones (Fig. 5a), suggested that these detritivores were using some $\mathrm{C}$ derived from S. patens.

Isotopic composition of plants and arthropods

In general, $\delta^{13} \mathrm{C}$ values of planthoppers and leafhoppers $(\sim-25 \%)$ revealed the use of $\mathrm{C}_{3}$ as opposed to $\mathrm{C}_{4}$ plants (Table 5; Fig. 6). There was one exception to this pattern. Planthoppers collected from the Spartina zone of site B were ${ }^{13} \mathrm{C}$-enriched relative to specimens collected from the other sites. $\delta^{13} \mathrm{C}$ values of the grasshoppers and katydids ( -27 to $-26 \%$ ) also indicated the principal use of $\mathrm{C}_{3}$ plants. $\delta^{13} \mathrm{C}$ values of spiders $(-25$ to $-24 \%$ ) overlapped 
Table 3 Mean $\delta^{13} \mathrm{C}$ and $\delta^{15} \mathrm{~N}$ values (\%o) of SOM and enchytraeid oligochaetes in vegetation zones dominated by either $\mathrm{C}_{4}$ (Spartina patens) or $\mathrm{C}_{3}$ (Juncus maritimus, Limonium dodartii) plants

\begin{tabular}{|c|c|c|c|c|c|}
\hline \multirow[t]{2}{*}{ Vegetation zone } & \multicolumn{2}{|l|}{ Carbon } & \multicolumn{2}{|l|}{ Nitrogen } & \multirow[t]{2}{*}{$n$} \\
\hline & SOM & Enchytraeid & SOM & Enchytraeid & \\
\hline Spartina patens $\left(\mathrm{C}_{4}\right)$ & $-21.1 \pm 1.7$ & $-20.6 \pm 1.6$ & $5.1 \pm 1.7$ & $5.4 \pm 1.0$ & 8 \\
\hline Juncus maritimus, Limonium dodartii $\left(\mathrm{C}_{3}\right)$ & $-24.2 \pm 1.8$ & $-23.1 \pm 0.7$ & $4.6 \pm 1.2$ & $6.2 \pm 0.7$ & 14 \\
\hline
\end{tabular}

Mean values $\pm 1 \mathrm{SD}, n=$ number of samples
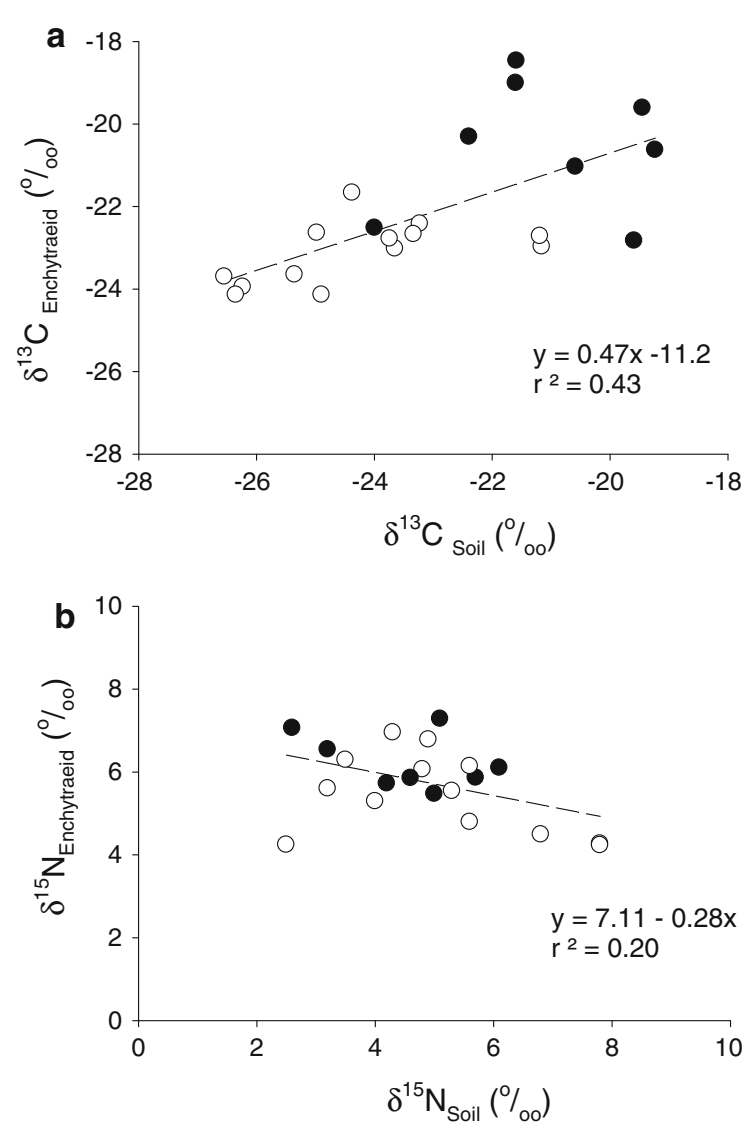

Fig. 5 Relationship between a $\delta^{13} \mathrm{C}$ values of SOM and enchytraeid oligochaetes and b $\delta^{15} \mathrm{~N}$ values of SOM and enchytraeid oligochaetes

values expected if these predators were consuming prey that were feeding primarily on $\mathrm{C}_{3}$ plants (Fig. 6). Overall, $\delta^{15} \mathrm{~N}$ values of herbivores ranged from -1.5 to $4.4 \%$ with no significant differences in mean values among vegetation zones. Two species of spiders were ${ }^{15} \mathrm{~N}$-enriched by at least $2-3 \%$ relative to potential herbivore prey (Table 5; Fig. 6).

\section{Discussion}

The occurrence of the non-indigenous Spartina patens in nearly monospecific stands in the upper marsh suggests that this plant has had negative impacts on native plant populations (SanLeón et al. 1999; this study). Stable isotope analysis provided one approach to explore less obvious impacts of this plant invasion on the ecological functions of upper marsh habitat, including the alteration of organic matter sources, which may ultimately influence soil properties, detritivore and herbivore populations and trophic pathways (Levin et al. 2006; Whitcraft et al. 2008). Our results suggest that inputs from $S$. patens have altered the source composition of SOM in the upper marsh, but have not yet completely displaced organic matter derived from $\mathrm{C}_{3}$ plants. This conclusion is based on the $\mathrm{C}$ isotope value of SOM in the Spartina zone, which was ${ }^{13} \mathrm{C}$-enriched relative to that of SOM in zones dominated by $\mathrm{C}_{3}$ vegetation.

Mixing model results provided a coarse estimate of the proportional contribution of Spartina patens $\mathrm{C}$ to SOM (mean values 35-63\%). Although we are not aware of published data for $S$. patens, isotope values of $S$. alterniflora plant litter have been shown to decrease during decomposition in low marsh sediments. These changes $(\sim-1$ to $-2 \%$ after $<2$ years, Ember et al. 1987; Benner et al. 1987), with relatively larger changes projected over time by modeling (Benner et al. 1987), are the result of the selective use of ${ }^{13} \mathrm{C}$-enriched compounds (e.g., cellulose) by microorganisms and the preservation of ${ }^{13} \mathrm{C}$-depleted refractory C (e.g., lignin) (Ember et al. 1987; Benner et al. 1987). In contrast, little change in the $\delta^{13} \mathrm{C}$ value of $S$. alterniflora occurred during aerial decomposition (Ember et al. 1987; Currin et al. 1995). Decreasing the values of the $S$. patens isotope end-member used in our mixing model to bracket 
Table 4 Estimates of percentage contribution of Spartina patens $\left(\mathrm{C}_{4}\right) \mathrm{C}$ to $\mathrm{SOM}$ in the Spartina zone

\begin{tabular}{lll}
\hline Scenario & $\begin{array}{l}\text { Shift in } \delta^{13} \mathrm{C}(\%) \\
\text { of } S \text {. patens source }\end{array}$ & $\begin{array}{l}\text { Estimated percentage } \\
(\%) \text { contribution from } S . \text { patens }\end{array}$ \\
\hline 1 & 0 & $35(17-52)$ \\
2 & -2 & 45 \\
3 & -4 & 63
\end{tabular}

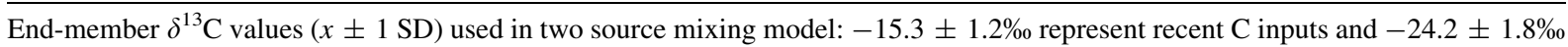
represent SOM values prior to invasion (Table 1). Estimate made under three scenarios: 1, no change in Spartina end-member values during decomposition, 2 , change in values by $-2 \%$ during decomposition, and 3 , change in values by $-4 \%$ during decomposition. 95\% CI for Scenario 1 only in parenthesis

Table $5 \delta^{13} \mathrm{C}$ and $\delta^{15} \mathrm{~N}$ values (\%o) of herbivorous insects and spiders sampled within vegetation zones dominated by Spartina patens, Limonium dodartii, or Juncus maritimus in Corrubedo wetlands

\begin{tabular}{|c|c|c|c|c|}
\hline Vegetation zone & Taxon & Site & $\delta^{13} \mathrm{C}(\%)$ & $\delta^{15} \mathrm{~N}(\%)$ \\
\hline \multirow[t]{6}{*}{ Limonium dodartii } & \multirow[t]{2}{*}{ Pentastiridius leporinus (L.) (Hemiptera, Cixidae) } & A & -25.5 & $-1.5(2)$ \\
\hline & & $\mathrm{C}$ & -24.6 & $-0.2(1)$ \\
\hline & Hemiptera, Cicadellidae & $\mathrm{C}$ & -25.1 & $4.0(2)$ \\
\hline & \multirow[t]{2}{*}{ Aiolopus strepens (Orthoptera, Acrididae) } & A & -26.2 & $2.8(1)$ \\
\hline & & $\mathrm{C}$ & -26.0 & $0.2(1)$ \\
\hline & Arachnida, Araneomorphae & A & $-24.2 \pm 0.4$ & $5.8 \pm 0.8(3)$ \\
\hline \multirow[t]{5}{*}{ Spartina patens } & \multirow[t]{2}{*}{ Pentastiridius leporinus } & A & $-25.3 \pm 1.4$ & $-0.2 \pm 0.4(4)$ \\
\hline & & $\mathrm{B}$ & $-19.6 \pm 0.8$ & $1.3 \pm 0.9(3)$ \\
\hline & Hemiptera, Cicadellidae & A & -25.6 & $1.8(1)$ \\
\hline & Orthoptera, Tettigoniidae & A & -26.9 & $4.4(2)$ \\
\hline & Arachnida, Araneomorphae & A & -23.5 & $7.5(2)$ \\
\hline \multirow[t]{7}{*}{ Juncus maritimus } & Pentastiridius leporinus & A & $-24.3 \pm 2.2$ & $0.1 \pm 0.5$ \\
\hline & \multirow[t]{3}{*}{ Hemiptera (F. Cicadellidae) } & A & -24.7 & $3.3(1)$ \\
\hline & & B & $-25.0 \pm 0.9$ & $1.2 \pm 1.4(3)$ \\
\hline & & $\mathrm{C}$ & $-24.6 \pm 0.4$ & $3.2 \pm 2.6(3)$ \\
\hline & Aiolopus strepens & A & -27.4 & $1.3(1)$ \\
\hline & Arachnida, Theraphosomorphae & A & -25.0 & $7.1(1)$ \\
\hline & Arachnida, Araneomorphae & $\mathrm{C}$ & -24.0 & $1.5(1)$ \\
\hline
\end{tabular}

Mean values $\pm 1 \mathrm{SD}$ when $n \geq 3$, sample size in parenthesis

values measured empirically or estimated from modeling for $S$. alterniflora increased the estimate of the proportional contribution of $S$. patens $\mathrm{C}$ to SOM. Inputs of other autochthonous (e.g., benthic algae) or allochthonous (e.g., phytoplankton) production that could also influence end-member values are probably minimal because of the high intertidal location, and thus only occasional inundation of our upper marsh sites.

One explanation for the apparent persistence of residual $\mathrm{C}_{3}$ plant-derived compounds in SOM within the Spartina patens zone is that the rate of incorporation of $\mathrm{C}_{4}-\mathrm{C}$ into $\mathrm{SOM}$ is slow relative to the timescale of this invasion (several decades). Unfortunately, there appear to be few data that have examined the replacement rates of $\mathrm{C}_{3}-\mathrm{C}$ by $\mathrm{C}_{4}-\mathrm{C}$ in Spartina-invaded salt marshes. In a recent invasion of an established native Scripus marquerter (a $\mathrm{C}_{3}$ plant) plant community by Spartina alterniflora (Jiuduansha wetlands, China, Cheng et al. 2006), the contribution of $S$. alterniflora $\mathrm{C}$ to SOM in invaded areas after 7 years was estimated to reach a maximum of $\sim 10 \%$ at a depth of $40 \mathrm{~cm}$, a value lower than the values estimated in the decades-old invasion in our study. 


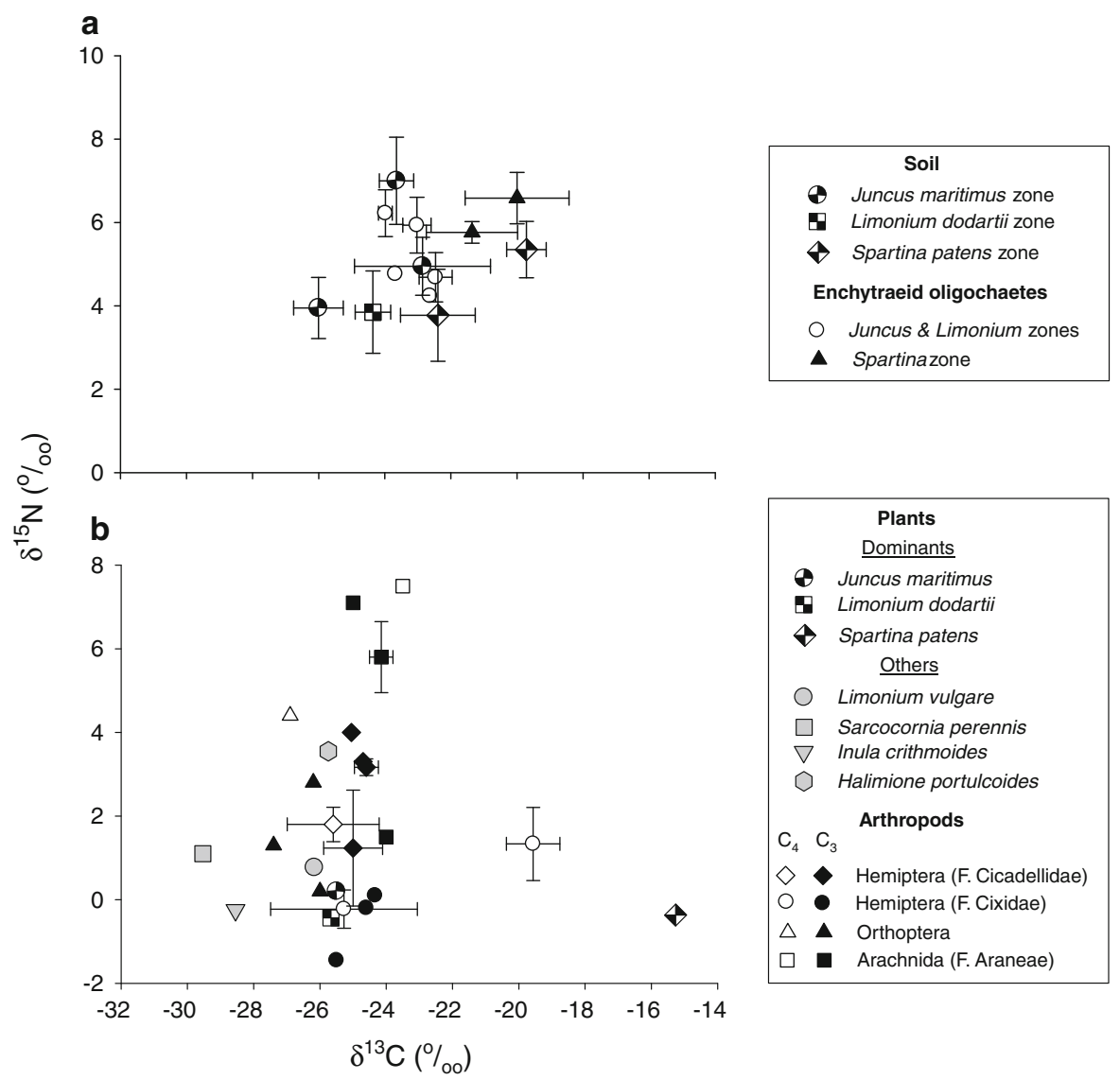

Fig. 6 Plot of $\delta^{15} \mathrm{~N}$ versus $\delta^{13} \mathrm{C}$ for a SOM and enchytraeid oligochaetes sampled in zones of $\mathrm{C}_{3}$ (Limonium and Juncus) and $\mathrm{C}_{4}$ (Spartina patens) vegetation and $\mathbf{b}$ dominant plant species, herbivorous insect taxa, and spiders. Mean values \pm 1 SD when $n \geq 3$

Enchytraeid oligochaetes incorporated $\mathrm{C}$ derived from Spartina patens, but did not have isotope values that indicated the preferential use of this recent source. The average isotopic enrichment of enchytraeids at our sites relative to the SOM $(+1.2 \%$ in the Limonium and Juncus zones, $+0.5 \%$ in Spartina zone, Table 2) was similar to the expected trophic enrichment factor of $\sim+1 \%$ (DeNiro and Epstein 1978). In this regard, our results agree with recent work in a terrestrial ecosystem, which indicated that enchytraeids were not preferentially incorporating the most recent $C$ inputs (Briones and Ineson 2002). This conclusion is further supported by reports of similar $\mathrm{C}$ and $\mathrm{N}$ isotope values in enchytraeids and endogeic earthworms, which use $\mathrm{C}$ derived from older decomposing material (Scheu and Falca 2000; Schmidt et al. 2004). It is also possible, however, that the input rates of organic matter from Spartina may not be great enough to reflect the preferential use of this recent $\mathrm{C}$ by enchytraeids. More data on the rates of contribution of $\mathrm{C}_{4}-\mathrm{C}$ to the SOM and of incorporation by detritivores will help to clarify the timescale across which $S$. patens invasions influence the composition and turnover of SOM and its use by soil detritivore populations.

Mean enchytraeid densites were higher $(3-5 x)$ in association with Spartina patens compared to areas where native plants dominated, including a site (C) that lacked $S$. patens from apparently suitable elevations. In other geographical settings, invasions of Spartina into low marsh and mudflat habitat have altered the density, composition, diversity and trophic structure of infaunal communities (Neira et al. 2005; Levin et al. 2006). It is thus possible that $S$. patens has also altered aspects of the upper marsh habitat (e.g., soil organic C) in ways that enhance enchytraeid abundance. The trend of higher enchytraeid densities in the Spartina zone, compared with the 
Limonium and Juncus zones, did not coincide with the elevational gradient in \% silt-clay, mean grain size, or \% organic C of SOM. However, enchytraeid densities could also be influenced by factors that co-vary with the cover of $S$. patens (e.g., inundation frequency, soil drainage, shade) not measured in this study.

The insects captured in net sweeps within the Spartina patens zone were dominated by herbivorous taxa, particularly the planthopper Pentastiridius leporinus (Hemiptera, Cixidae). P. leporinus is found in wetland-upland transition habitats in western Europe with Phragmites australis reported as a host plant in other areas (Nickel and Remane 2002). Interestingly, this insect is a vector of bacterial disease to sugar beets in southern France (Bressan et al. 2010). P. leporinus was not among those identified as insect herbivores occurring in patches of S. patens along the New Jersey (Atlantic) coast, USA, which were mostly flightless forms (Denno 1977, 1980). In this regard, our data supports the observation that insect herbivores that would normally feed on the introduced plant species within its native range may be absent in the invaded habitat (Ohmart and Edwards 1991; Bell 1997; Maron and Vilà 2001).

Most of the herbivorous insects associated with Spartina patens in its native habitat are host specific (Davis and Gray 1966; Denno 1977). However, there was no evidence that herbivorous insects at our study sites preferred $S$. patens over native $\mathrm{C}_{3}$ plants or that $S$. patens was widely used as a source of food by these taxa, at least during a period of time prior to our sampling that would be reflected in the stable isotope values of these consumers. Indeed, insect herbivores captured within both $\mathrm{C}_{3}$ (Limonium, Juncus) and $\mathrm{C}_{4}$ (Spartina) vegetation zones had $\mathrm{C}$ isotope signatures reflecting the use of $\mathrm{C}_{3}$ plants. The proposed use of mainly $\mathrm{C}_{3}$ plants by insect herbivores is further supported by the ${ }^{13} \mathrm{C}$-depleted isotope values of potential predators (spiders) from the Spartina zone (site A). There was one exception to this general pattern; planthoppers from the Spartina zone at one site (B) had intermediate $\mathrm{C}$ isotope values that suggested some use $S$. patens by sap-feeders.

Our findings suggest that herbivore use of Spartina patens is not as extensive as that found in its native range, where this plant is fed on heavily by several hemipteran species (Davis and Gray 1966; Denno 1980). At our sites, it appears that mobile herbivores transit the Spartina zone, but apparently are not feeding extensively on this plant. In contrast, Denno (1980) reported that during the summer, the population of sap-feeding insects on large patches (500$1,000 \mathrm{~m}^{2}$ ) of $S$. patens in a New Jersey coastal marsh was high and the effects of feeding and oviposition were evident by the deterioration of the grass over time. Our results also differ from those of Wu et al. (2009), which suggested that some native taxa, katydids (F. Tettigoniidae) and crickets (F. Gryllidae), preferred the exotic Spartina (S. alteniflora) over the native Phragmites australis in a salt marsh in the Yangtze River estuary (China). We conducted our sampling during late May, a time period likely to have a high abundance of both enchytraeids and insects, and high food resource use in the study region. However, data on temporal variability in enchytraeid and insect populations is needed to assess to what extent our results may apply to other times of the year.

In conclusion, the elevated abundance of enchytraeids in association with Spartina patens and their use of $\mathrm{C}$ derived from this plant suggest that dense patches of $S$. patens may facilitate detritivore populations, and thus could indirectly influence soil attributes and processes that are mediated by detritivore activity, such as soil respiration rates, nutrient retention and transformation, energy flow, and habitat architecture (Moore et al. 2004). In contrast, although insect herbivores used $S$. patens as habitat, there was little isotopic evidence for the widespread incorporation of $S$. patens-derived $\mathrm{C}$ by these consumers. The loss of food resources to insect herbivores alters local food webs, but insect herbivores may move and feed on native plants outside of the Spartina zone. As a result, insect populations may be less immediately impacted than soil detritivore populations by the shift from native plants to $S$. patens in the upper marsh.

The distribution of Spartina patens is expanding in northern Spain (Campos et al. 2004) and this species is recognized as undesirable in this region and elsewhere (Frenkel and Boss 1988; Ayres et al. 2004); however, few studies have explored potential consequences of $S$. patens invasion on salt marsh functioning. Our study suggests that the impacts of $S$. patens invasion may extend beyond the more obvious changes in native plant abundance, to include differing responses in the cycling of organic matter between detritivore and insect herbivore food web pathways. 
Acknowledgments We thank the authorities of the Corrubedo Nature Park for permission to work in this wetland and for technical assistance. We also thank D. Aguín-Pombo for assistance with insect taxonomy, and J. Dugan and two anonymous referees for comments on the manuscript. This research was supported by the "Secretaría General para el Territorio y la Biodiversidad" of the Spanish Ministry of Environment (030/SGTB/2007).

Open Access This article is distributed under the terms of the Creative Commons Attribution Noncommercial License which permits any noncommercial use, distribution, and reproduction in any medium, provided the original author(s) and source are credited.

\section{References}

Ayres DR, Zaremba DI, Klohr K, Strong DR (2004) Spread of exotic cordgrasses and hybrids (Spartina sp.) in the tidal marshes of San Francisco Bay. Biol Invasions 6:221-231

Bell GP (1997) Ecology and management of Arundo donax, and approaches to riparian habitat restoration in southern California. In: Brock JH, Wade M, Pysêk P, Green D (eds) Plant invasions: studies from North America, Europe. Backhuys, Leiden, pp 103-113

Benner R, Fogel ML, Sprague EK, Hodson RE (1987) Depletion of $13 \mathrm{C}$ in lignin and its implications for stable carbon isotope studies. Nature 329:708-710

Bertness MD (1991) Zonation of Spartina patens and Spartina alterniflora in a new England salt marsh. Ecology 72:138148

Blum JL (1968) Salt marsh spartinas and associated algae. Ecol Monogr 38:199-221

Boutton TW (1996) Stable carbon isotope ratios of soil organic matter and their use as indicators of vegetation and climate change. In: Boutton TW, Yamasaki S-I (eds) Mass spectrometry of soils. Marcel Dekker, New York, pp 47-81

Bressan A, Moral García FJ, Sémétey O, Boudon-Padieu E (2010) Spatio-temporal pattern of Pentastiridius leporinus migration in an ephemeral cropping system. Agric For Entomol 12:59-68

Briones MJI, Ineson P (2002) Use of ${ }^{14} \mathrm{C}$ carbon dating to determine feeding behaviour of enchytraeids. Soil Biol Biochem 34:881-884

Briones MJI, Schmidt O (2004) Stable isotope techniques in studies of the ecological diversity and function of earthworm communities in agricultural soils. Rec Res Dev Crop Sci 1:11-26

Callaway JC, Josselyn MN (1992) The introduction and spread of smooth cordgrass (Spartina alterniflora) in South San Francisco Bay. Estuaries 15:218-226

Campos JA, Herrera M, Biurrun I, Loidi J (2004) The role of alien plants in the natural coastal vegetation in centralnorthern Spain. Biodivers Conserv 13:2275-2293

Castillo JM, Fernandez-Baco L, Castellanos EM, Luque CJ, Figueroa ME, Davy AJ (2000) Lower limits of Spartina densiflora and $S$. maritima in a Mediterranean salt marsh determined by different ecophysiological tolerances. J Ecol 88:801-812
Chambers RM, Meyerson LA, Saltonstall K (1999) Expansion of Phragmites australis into tidal wetlands of North America. Aquat Bot 64:261-274

Chen H, Bo L, Hu J, Chen J, Wu J (2007) Effects of Spartina alterniflora invasion on benthic nematode communities in the Yangtze Estuary. Mar Ecol Prog Ser 336:99-110

Cheng X, Luo Y, Chen J, Lin G, Chen J, Li B (2006) Short-term $\mathrm{C}_{4}$ plant Spartina alterniflora invasions change the soil carbon in $\mathrm{C}_{3}$ plant-dominated tidal wetlands on a growing estuarine Island. Soil Biol Biochem 38:3380-3386

Cronk QCB, Fuller JL (1995) Plant invaders. Chapman and Hall, London, UK

Currin CA, Newell SY, Paerl HW (1995) The role of standing dead Spartina alterniflora and benthic microalgae in salt marsh food webs: considerations based on multiple stable isotope analysis. Mar Ecol Prog Ser 121:99-116

Daehler CC, Strong DR (1996) Status, prediction and prevention of introduced cordgrass Spartina spp invasions in Pacific estuaries. USA. Biol Conserv 78:51-58

Davis LV, Gray IE (1966) Zonal and seasonal distribution of insects in North Carolina salt marshes. Ecol Monogr 36:275-295

DeNiro MJ, Epstein S (1978) Influence of diet on the distribution of carbon isotopes in animals. Geochim Cosmochim Acta 42:495-506

Denno RF (1977) Comparison of the assemblages of sapfeeding insects (Homoptera-Hemiptera) inhabiting two structurally different salt marsh grasses in the genus Spartina. Environ Entomol 6:359-372

Denno RF (1980) Ecotope differentiation in a guild of sapfeeding insects on the salt marsh grass, Spartina patens. Ecology 6:702-714

Dethier MN, Hacker SD (2005) Physical factors vs. biotic resistance in controlling the invasion of an estuarine marsh grass. Ecol Appl 15:1273-1283

Ember LM, Williams DF, Morris JT (1987) Processes that influence carbon isotope variations in salt marsh sediments. Mar Ecol Prog Ser 36:33-42

Frenkel RE, Boss TR (1988) Introduction, establishment and spread of Spartina patens on Cox Island, Siuslaw Estuary, Oregon. Wetlands 8:33-49

Fry B (2006) Stable isotope ecology. Springer, New York

Fry B, Joren A, Parker PL (1978) Grasshopper food web analysis: use of carbon isotope ratios to examine feeding relationships among terrestrial herbivores. Ecology 59: 498-506

Gratton C, Denno RF (2006) Arthropod food web restoration following removal of an invasive wetland plant. Ecol Appl 16:622-631

Hobbs RJ, Huenneke LF (1992) Disturbance, diversity, and invasion - implications for conservations. Conserv Biol 6:324-337

Levin LA, Neira C, Grosholz ED (2006) Invasive cordgrass modifies wetland trophic function. Ecology 87:419-432

Levine JM, D'Antonio CM, Dukes JS, Grigulis K, Lavore S (2003) Mechanisms underlying the impacts of exotic plant invasions. Proc R Soc Biol Sci 270:775-781

Mack RN, Simberloff D, Lonsdale WM, Evans H, Clout M, Bazzaz FA (2000) Biotic invasion: causes, epidemiology, global consequences, and control. Ecol Appl 10:689-710 
Maron JL, Vilà M (2001) When do herbivores affect plant invasion? Evidence for the natural enemies and biotic resistance hypotheses. Oikos 95:361-373

Martin A, Balesdent J, Mariotti A (1992) Earthworm diet related to soil organic matter dynamics through ${ }^{13} \mathrm{C}$ measurements. Oecologia 91:23-29

Moore JC, Berlow EL, Coleman DC, de Ruiter PC, Dong Q, Hastings A, Johnson NC, McCann KS, Melville K, Morin PJ, Nadelhoffer K, Rosemond AD, Post DM, Sabo JL, Scow KM, Vanni MJ, Wall DH (2004) Detritus, trophic dynamics and biodiversity. Ecol Lett 7:584-600

Nehring S, Hesse KJ (2008) Invasive alien plants in marine protected areas: the Spartina anglica affair in the European Wadden Sea. Biol Invasions 10:937-950

Neira C, Levin LA, Grosholz ED (2005) Benthic macrofaunal communities of three sites in San Francisco Bay invaded by hybrid Spartina, with comparison to uninvaded habitats. Mar Ecol Prog Ser 292:111-126

Neira C, Grosholz ED, Levin LA, Blake R (2006) Mechanisms generating modification of benthos following tidal flat invasion by a Spartina hybrid. Ecol Appl 16:1391-1404

Nickel H, Remane R (2002) Check list of the planthoppers and leafhoppers of Germany, with notes on food plants, diet width, life cycles, geographic range and conservation status (Hemiptera, Fulgoromorpha and Cicadomorpha). Beitr zur Zikade 5:27-64 (English translation of original, Artenliste der Zikaden Deutschlands, mit Angabe von Nährpflanzen, Nahrungsbreite, Lebenszyklus, Areal und Gefährdung (Hemiptera, Fulgoromorpha et Cicadomorpha)) only available as pdf (http://www.gwdg.de/ hnickel)

Nieva FJJ, Díaz-Espejo A, Castellanos EM, Figueroa ME (2001) Field variability of invading populations of Spartina densiflora Brong. in different habitats of the Odiel marshes (SW Spain). Estuar Coast Shelf Sci 52:515-527

O'Connor FB (1955) Extraction of enchytraeid worms from a coniferous forest soil. Nature 175:815-816

Ohmart CP, Edwards PB (1991) Insect herbivory on Eucalyptus. Annu Rev Entomol 36:637-657

Petelle M, Haines B, Haines E (1979) Insect food preferences analysed using ${ }^{13} \mathrm{C} /{ }^{12} \mathrm{C}$ ratios. Oecologia 38:159-166

Phillips DL, Gregg JW (2001) Uncertainty in source partitioning using stable isotopes. Oecologia 127:171-179

Raupp MJ, Denno RF (1979) The influence of patch size on a guild of sap-feeding insects that inhabit the salt marsh grass Spartina patens. Environ Entomol 8:412-417
Redfield AC (1972) Development of a New England salt marsh. Ecol Monogr 42:201-237

Renny-Byfield S, Ainouche M, Leitch IJ, Lim KY, Le Comber SC, Leitch AR (2010) Flow cytometry and GISH reveal mixed ploidy populations and Spartina nonaploids with genomes of $S$. alterniflora and S. maritima origin. Ann Bot 105:527-533

Sánchez JM, Izco J, Medrano M (1996) Relationships between vegetation zonation and altitude in a salt-marsh system in northwest Spain. J Veg Sci 7:695-702

SanLeón DG, Izco J, Sánchez JM (1999) Spartina patens as a weed in Galician saltmarshes (NW Iberian Peninsula). Hydrobiologia 415:213-222

Scheu S, Falca M (2000) The soil food web of two beech forests (Fagus sylvatica) of contrasting humus type: stable isotope analysis of a macro- and a mesofauna-dominated community. Oecologia 123:285-286

Schmidt O, Curry JP, Dyckmans J, Rota E, Scrimgeour CM (2004) Dual stable isotope analysis (delta C-13 and delta $\mathrm{N}-15$ ) of soil invertebrates and their food sources. Pedobiologia 48:171-180

Simberloff D (2005) Non-native species do threaten the natural environment!. J Agric Environ Ethics 18:595-607

Talley TS, Levin LA (2001) Modification of sediments and macrofauna by an invasive marsh plant. Biol Invasions 3:51-68

van Vliet PCJ, Beare MH, Coleman DC, Hendrix PF (2004) Effects of enchytraeids (Annelida: Oligochaeta) on soil carbon and nitrogen dynamics in laboratory incubations. Appl Soil Ecol 25:147-160

Vitousek PM, D’Antonio CM, Loope LL, Westbrooks R (1996) Biological invasions as global environmental changes. Am Sci 84:468-478

Wentworth CK (1922) A scale of grade and class terms for clastic sediments. J Geol 30:377-392

Whitcraft CR, Levin LA, Talley D, Crooks JA (2008) Utilization of invasive tamarisk by salt marsh consumers. Oecologia 158:259-272

Wu Y-T, Wang C-H, Zhang X-D, Zhao B, Jiang L-F, Chen JK, Li B (2009) Effects of saltmarsh invasion by Spartina alterniflora on arthropod community structure and diet. Biol Invasions 11:635-649

Zhang RS, Shen YM, Lu LY, Yan SG, Wang YH, Li JL, Zhang ZL (2004) Formation of Spartina alterniflora salt marshes on the coast of Jiangsu province, China. Ecol Eng 23:95-105 